\title{
PERBEDAAN PEMAHAMAN MAHASISWA S1 MANAJEMEN DENGAN S1 AKUNTANSI TENTANG SIKLUS AKUNTANSI
}

\author{
Asih Niati ${ }^{1}$ \\ Fakultas Ekonomi,_Jurusan Manajemen_Universitas Semarang \\ asih_niati@usm.ac.id ${ }^{1}$ \\ Tri Rinawati ${ }^{2}$ \\ Fakultas Ekonomi,_Jurusan Manajemen_Universitas Semarang \\ tri_rinawati@usm.ac.id²
}

\begin{abstract}
ABSTRAK
Pemahaman mahasiswa pada mata kuliah akuntansi khususnya tentang siklus akuntansi bervariasi, hal ini tergantung pada tingkat kecerdasan mahasiswa. Pemahaman adalah menguasai sesuatu dengan pikiran, mengerti secara mental dan filosofinya, maksud dan implikasinya serta aplikasinya, sehingga menyebabkan mahasiswa dapat memahami suatu situasi. Tujuan penelitian untuk mengetahui perbedaan pemahaman tentang siklus akuntansi antara mahasiswa S1 Manajemen dengan mahasiswa S1 Akuntansi.

Populasi pada penelitian ini adalah mahasiswa S1 Akuntansi dan mahasiswa S1 Manajemen Semester Genap tahun ajaran 2018/2019. Penarikan sampel dilakukan dengan menggunakan pendekatan Slovin. Teknik pengambilan sampel 100 orang mahasiswa (50 mahasiswa S1 Manajemen dan 50 mahasiswa S1 Akuntansi) dilakukan dengan menggunakan purposive sampling.

Teknik analisa data menngunakan uji statistik deskriptif, uji kualitas data, uji asumsi klasik, uji independent sample t test.

Berdasarkan uji koefisien kontingensi, disimpulkan bahwa terdapat hubungan yang signifikan antara pemahaman mahasiswa S1 Akuntansi dan S1 manajemen tentang siklus akuntansi yang ditunjukkan berdasarkan hasil nilai yang diperoleh mahasiswa. Akan tetapi tidak terdapat hubungan yang signifikan antara pemahaman mahasiswa S1 Akuntansi dan S1 manajemen berdasarkan jenis kelamin tentang siklus akuntansi yang ditunjukkan berdasarkan hasil nilai yang diperoleh mahasiswa. Berdasarkan uji Pearson ChiSquare, disimpulkan bahwa terdapat hubungan yang signifikan antara pemahaman mahasiswa program studi S1 Manajemen dan S1 Akuntansi tentang Siklus Akuntansi yang ditunjukkan pada hasil nilai mahasiswa.
\end{abstract}

Kata Kunci : Expected Return, Risk, Penilaian Saham

\section{PENDAHULUAN}

\section{Latar Belakang Masalah}

Pemahaman mahasiswa pada mata kuliah akuntansi khususnya tentang siklus akuntansi bervariasi, hal ini tergantung pada tingkat kecerdasan mahasiswa. Pemahaman menurut Sudjiono (2013), adalah menguasai sesuatu dengan pikiran, mengerti secara mental dan filosofinya, maksud dan implikasinya serta aplikasinya, sehingga menyebabkan mahasiswa dapat memahami suatu situasi.

Berdasarkan hasil survey dari terhadap 199 mahasiswa dengan mengambil sampel dosen pengampu dua orang yang berbeda untuk masingmasing program studi. Nilai Akuntansi yang diambil hanya nilai A, B dan C. Hasil survey nilai akuntansi yang tampak pada tabel 1.1, mahasiswa dengan program studi S1 Akuntansi untuk dosen pengampu satu, mahasiswa dengan nilai $\mathrm{A}$ berjumlah 22 orang, nilai B berjumlah 24 orang dan nilai $C$ berjumlah 4 orang. Sedangkan untuk dosen pengampu dua, mahasiswa dengan nilai $\mathrm{A}$ berjumlah 11 orang, nilai $\mathrm{B}$ berjumlah 21 orang dan nilai $\mathrm{C}$ berjumlah 19 orang. Mahasiswa dengan program studi S1 Manajemen untuk dosen pengampu satu, mahasiswa dengan nilai A berjumlah 15 orang, nilai $\mathrm{B}$ berjumlah 23 orang dan nilai $C$ berjumlah 1 orang. Sedangkan untuk dosen pengampu dua, mahasiswa dengan nilai $\mathrm{A}$ berjumlah 17 orang, nilai $\mathrm{B}$ berjumlah 47 orang dan nilai $\mathrm{C}$ berjumlah 2 orang. Berdasarkan hasil survey tersebut dapat disimpulkan bahwa pemahaman mahasiswa terhadap akuntansi adalah rata-rata.

Penelitian yang dilakukan oleh Maryati (2017), disimpulkan bahwa motivasi belajar, gaya 
belajar, perilaku belajar tidak berpengaruh terhadap tingkat pemahaman akuntansi. Namun terdapat faktor lain yang mempengaruhi seperti usia dan jenis kelamin. Faktor lainnya yang membuat mahasiswa mendapatkan nilai seperti keterpaksanaan dan pengalaman. Serta ada faktor lain yang mempengaruhi yaitu kebiasaan yang kurang baik yaitu waktu belajar yang tidak teratur dan kebiasaan membaca yang buruk, adanya tekanan mental dan bahan pelajaran yang dibaca tidak sesuai dengan harapan. Adapun penelitian lain yang dilakukan oleh Hartono dan Bangun (2011), disimpulkan bahwa pertama, mahasiswa akuntansi dengan latar belakang pendidikan menengah atas yang meliputi SMK jurusan akuntansi, SMU IPS dan SMU IPA memliki pemahaman yang sama terhadap konsep aset, kewajiban dan ekuitas. Kedua, latar belakang pendidikan menengah atas tidak memicu perbedaan pemahaman atas ketiga konsep tersebut. Pemahaman asset mencakup asset lancer, investasi jangka panjang asset tetap, dan asset tidak berwujud. Pemahaman modal menekankan pada komponen ekuitas perusahaan yang berbeda-beda sesuai dengan bentuk perusahaannya.

Berdasarkan hasil penelitian terdahulu, disimpulkan bahwa pemahaman mahasiswa terhadap mata kuliah akuntansi dipengaruhi oleh usia, jenis kelamin, keterpaksanaan dan pengalaman, kebiasaan yang kurang baik yaitu waktu belajar yang tidak teratur dan kebiasaan membaca yang buruk, adanya tekanan mental dan bahan pelajaran yang dibaca tidak sesuai dengan harapan. Apabila dilihat dari latar belakang asal pendidikan SMU bahwa tidak ada perbedaan pemahaman antara mahasiswa dari SMU atau SMK baik yang jurusan IPA, IPS atau Akuntansi.

\section{TINJAUAN TEORITIS PENGEMBANGAN HIPOTESIS Sistem Informasi}

Sistem informasi manajemen merupakan sistem yang terpadu antara user dan aplikasi yang memberikan informasi untuk mendukung jalannya operasional manajemen dan fungsi pembentukan keputusan di dalam organisasi. Sistem Informasi Manajemen menurut McLeod (2009), adalah system berbasis komputer yang membuat informasi tersedia bagi para pengguna yang memiliki kebutuhan serupa.

\section{Siklus Akuntansi}

Siklus Akuntansi merupakan gambaran tahapan kegiatan akuntansi yang meliputi pencataatan, penggolongan, pengikhtiaran dan pelaporan yang dimulai saat terjadi sebuah transaksi dalam suatu perusahaan Fitria (2014). Adapun menurut Pura (2013), siklus akuntansi merupakan serangkaian kegiatan akuntansi yang dilakukan secara sistematika dimulai dari pencatatan akuntansi sampai dengan penutupan pembukuan.

\section{Tahapan-tahapan Akuntansi}

Tahapan-tahapan dalam siklus akuntansi dapat diurutkan mulai dari transaksi atau dokumen pendukung, posting buku besar, saldo akhir pada masing-masing buku besar dikumpulkan ke neraca saldo, menganalisis data penyesuaian dan membuat ayat jurnal penyesuaian, postingkan kembali ke buku besar, membuat kerja kerja (worksheet) sebagai bantuan untuk membuat neraca saldo setelah penyesuaian, membuat laporan keuangan, membuat ayat jurnal penutup dan postingkan kembali ke buku besar, kemudian saldo akhir dikumpulkan ke neraca saldo setelah penutupan, terakhir membuat ayat jurnal pembalik (Hery, 2014).

\section{Pemahaman}

Pemahaman adalah kemampuan seseorang untuk mengerti atau memahami sesuatu untuk diketahui dan diingat. Hasil belajar pemahaman merupakan tipe belajar yang lebih tinggi dibandingkan tipe belajar pengetahuan Sudijono (2009). Menurut Suharsimi (2009), pemahaman adalah bagaimana seseorang mempertahankan, membedakan, menduga, menerangkan, memperluas, menyimpulkan, menggeneralisasi, memberikan contoh, menulis kembali dan memperkirakan. Adapun menurut Daryanto (2008), menjelaskan bahwa kemampuan pemahaman berdasarkan tingkat kepekaan dan derajat penyerapan materi, yaitu menterjemahkan, menafsirkan dan mengekstrapolasi.

\section{Penelitian Terdahulu}

Penelitian yang dilakukan oleh Rusmita (2012), menyimpulkan bahwa tidak ada perbedaan pemahaman konsep dasar akuntansi yang signifikan antara mahasiswa yang berasal dari SMA jurusan IPA dan SMA jurusan IPS, tidak ada perbedaan pemahaman konsep dasar akuntansi yang signifikan antara mahasiswa yang berasal dari SMA jurusan IPA dan SMK jurusan Akuntansi dan terdapat perbedaan pemahaman konsep dasar akuntansi yang signifikan antara mahasiswa yang berasal dari SMA jurusan IPS dan SMK jurusan Akuntansi. 
Penelitian yang dilakukan oleh Biduri (2016), disimpulkan bahwa tidak ada pengaruh pemahaman konsep dasar akuntansi yang signifikan antara mahasiswa yang berlatar belakang pendidikan SMA-IPA dan SMA-IPS.

Penelitian yang dilakukan oleh Novius (2010), menyatakan bahwa tidak terdapat perbedaan secara signifikan terhadap pemahaman tentang aktiva, kewajiban dan modal antara mahasiswa yang berasal dari SMK Jurusan Akuntansi, SMA jurusan IPS dan Madrasah Aliyah Umum. Kesimpulan bahwa pemahaman mahasiswa terhadap dasardasar akuntansi tidaklah berbeda ataupun identic antara satu sama lainnya tidaklah menjadi faktor perbedaan bagi mahasiswa untuk memahami dasar-dasar akuntansi.

Penelitian yang dilakukan oleh Efriyenti (2017), disimpulkan bahwa tidak terdapat perbedaan terhadap pemahaman asset, kewajiban dan ekuitas antara mahasiswa yang berasal dari SMK jurusan Akuntansi, SMA IPS dan SMA IPA yang menunjukkan bahwa latar belakang pendidikan menegah atas tidak memicu perbedaan pemahaman atas ketiga konsep tersebut. Penelitian ini memiliki sejumlah keterbatasan, yaitu jumlah responden relative kecil karena hanya berasal dari satu perguruan tinggi di Universitas Internasional Batam.

\section{Hubungan Logis Antar Variabel dan Pengembangan Hipotesis \\ Pemahaman mahasiswa S1 Manajemen dan S1 Akuntansi pada Siklus Akuntansi}

Definisi Siklus Akuntansi menurut Fitria (2014) merupakan gambaran tahapan kegiatan akuntansi yang meliputi pencatatan, penggolongan, pengikhtiaran dan pelaporan yang dimulai saat terjadi sebuah transaksi dalam suatu perusahaan. Sedangkan Pemahaman menurut Sudjiono (2009) adalah kemampuan seseorang untuk mengerti atau memahami sesuatu untuk diketahui dan diingat. Hasil belajar pemahaman merupakan tipe belajar yang lebih tinggi dibandingkan tipe belajar pengetahuan.

Penelitian yang dilakukan oleh Rusmita (2012), Biduri (2016), Novius (2010), dan Efriyenti (2017), masing-masing menyimpulkan bahwa tidak ada perbedaan pemahaman mahasiswa berdasarkan latar belakang pendidikan, tidak ada perbedaan pemahaman mahasiswa tentang akuntansi dan sejenisnya yang terkait. Berdasarkan beberapa argument tersebut diatas, maka dapat ditarik hipotesis sebagai berikut :
H1 : Terdapat perbedaan pemahaman mahasiswa S1 Manajemen dan S1 Akuntansi tentang Siklus Akuntansi

\section{Kerangka Pemikiran}

Gambar 1. Kerangka Pemikiran

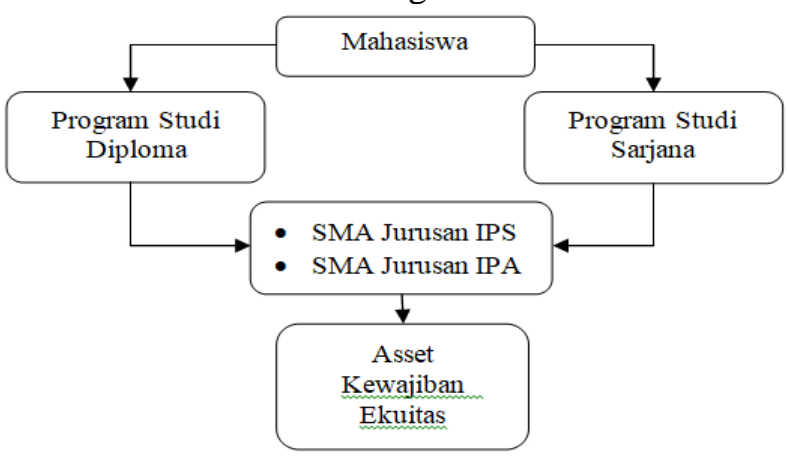

\section{Hipotesis}

Hipotesis berikut dikembangkan dan diuji untuk mencapai tujuan :

Hipotesis 1 : terdapat perbedaan signifikan terhadap pemahaman tentang Aset antara mahasiswa Program Studi Diploma dan Program Studi Sarjana berdasarkan latar pendidikan SMA IPA dan SMA IPS.

Hipotesis 2 : terdapat perbedaan signifikan terhadap pemahaman tentang kewajiban antara mahasiswa Program Studi Diploma dan Program Studi Sarjana berdasarkan latar pendidikan SMA IPA dan SMA IPS.

Hipotesis 3 : terdapat perbedaan signifikan terhadap pemahaman tentang modal antara mahasiswa Program Studi Diploma dan Program Studi Sarjana berdasarkan latar pendidikan SMA IPA dan SMA IPS.

\section{METODE PENELITIAN}

\section{Lokasi Penelitian dan Waktu Penelitian}

Lokasi penelitian merupakan suatu tempat atau wilayah dimana penelitian tersebut akan dilakukan. Penelitian dilakukan di lingkungan kampus Universitas Semarang khususnya Fakultas Ekonomi, studi pada mahasiswa akuntansi jenjang strata satu jurusan Manajemen dan Akuntansi. Penelitian dilaksanakan selama 3 bulan.

\section{Populasi dan Sampel}

Populasi pada penelitian ini adalah mahasiswa S1 Akuntansi dan mahasiswa S1 Manajemen Semester Genap tahun ajaran 2018/2019. Jumlah mahasiswa yang dijadikan populasi yaitu 
mahasiswa S1 Manajemen sebanyak 565 orang dan mahasiswa S1 Akuntansi sebanyak 428 orang.

Penarikan sampel dilakukan dengan menggunakan pendekatan Slovin, yang diketahui sampel penelitian sebanyak 100 orang. Teknik pengambilan sampel 100 orang mahasiswa ( 50 mahasiswa S1 Manajemen dan 50 mahasiswa S1 Akuntansi) dilakukan dengan menggunakan purposive sampling, dimana pengambilan sampel dilakukan berdasarkan atas suatu pertimbangan seperti sifat-sifat populasi ataupun ciri-ciri yang sudah diketahui sebelumnya (Notoatmojo, 2010). Adapun kriteria tersebut diantaranya mahasiswa program studi Manajemen dan Akuntansi berjenjang strata satu, mahasiswa semester Genap 2018/2019 yang mengambil mata kuliah akuntansi biaya dengan alasan sudah pernah mengikuti mata kuliah pengantar akuntansi/akuntansi dagang jasa.

\section{Jenis dan Sumber Data}

Jenis data yang digunakan dalam penelitian ini adalah Data Kualitatif. Sumber data yang digunakan dalam penelitian ini terdiri dari dua macam yaitu data primer dan data sekunder. Data primer adalah data yang diperoleh melalui observasi atau pengamatan langsung dari perusahaan, baik itu melalui observasi, kuisioner, dan wawancara secara langsung dengan mahasiswa sesuai dengan kebutuhan dalam penelitian ini. Sedangkan data sekunder merupakan data yang diperoleh tidak langsung, yaitu data tersebut diperoleh penulis dari jurnal-jurnal dari internet dan buku-buku literatur yang dapat memberikan informasi mengenai siklus akuntansi dan hal-hal yang membuat mahasiswa untuk memahami tentang siklus akuntansi.

\section{Metode Pengumpulan Data}

Proses pengumpulan data yang diperlukan melalui dua tahap, yaitu: Studi Lapangan dan Studi Kepustakaan. Penelitian lapangan dilakukan dengan cara wawancara, observasi dan kuesioner.

\section{Variabel Penelitian}

Variabel yang diamati pada penelitian ini adalah Mahasiswa S1 Manajemen dan S1 Akuntansi semester genap tahun ajaran 2018/2019 Unversitas Semarang dan Pemahaman mahasiswa tentang Siklus Akuntansi.
Definisi Operasional dan Pengukuran Variabel

Tabel 1. Definisi Operasional dan Pengukuran Variabel

\begin{tabular}{|c|c|c|}
\hline Variabel & Definisi Variabel & Indikator \\
\hline Pemahaman & $\begin{array}{lr}\text { Pemahaman } & \text { adalah } \\
\text { kemampuan seseorang untuk } \\
\text { mengett atau memahami } \\
\text { sesuatu untuk diketahui dan } \\
\text { diingat. Hasil belajar } \\
\text { pemahaman merupakan tipe } \\
\text { belajar yang lebih tinggi } \\
\text { dibandingkan tipe belajar } \\
\text { pengetahuan Sudijono (2009). }\end{array}$ & $\begin{array}{l}\text { - Pencatatan } \\
\text { - Penggolongan } \\
\text { - Pengikhtisaran }\end{array}$ \\
\hline Siklus Akuntansi & $\begin{array}{l}\text { Siklus akuntansi merupakan } \\
\text { serangkaian kegiatan akuntansi } \\
\text { yang dilakukan secara } \\
\text { sistematika dimulai dari } \\
\text { pencatatan akuntansi } \\
\text { dengampai } \\
\text { Pura (2013). }\end{array}$ & $\begin{array}{l}\text { - Jumal } \\
\text { - Buku Besar } \\
\text { - Neraca Saldo } \\
\text { - Jumal Penyesuaian } \\
\text { - Neraca Saldo Setelah } \\
\text { Penyesuaian } \\
\text { - Neraca Lajur } \\
\text { - Laporan Keuangan } \\
\text { - Jumal Penutup } \\
\text { - Neraca Saldo Setelah } \\
\text { - Jenutupan } \\
\text { - Jumal Pembalik }\end{array}$ \\
\hline
\end{tabular}

\section{Teknik Analisa Data \\ Analisis Statistik Deskriptif}

Statistik Deskriptif adalah metode yang digunakan untuk menganalisis data dengan cara mendeskripsikan atau menggambarkan data yang telah terkumpul sebagaimana adanya tanpa bermaksud membuat kesimpulan yang berlaku untuk umum atau generalisasi (Sugiyono, 2017).

\section{Analisis Bivariat Chi Square}

Menurut Azis (2014), Uji Chi-square adalah teknik analisis yang digunakan untuk menentukan perbedaan frekuensi observasi (Oi) dengan frekuensi ekspektasi atau frekuensi harapan (Ei) suatu kategori tertentu yang dihasilkan. Uji ini dapat dilakukan pada data diskrit atau frekuensi. Rumus :

$$
\mathrm{X}^{2}=\Sigma \frac{(\mathrm{O}-\mathrm{E})^{2}}{\mathrm{E}}
$$

Dimana df $=(\mathrm{k}-1)(\mathrm{b}-1)$

Keterangan :

$X^{2}=$ Nilai Chi Square; $\Sigma=$ Jumlah responden yang diamati; $\mathrm{O}=$ Nilai yang diamati $\mathrm{E}=$ Nilai yang diharapkan; $\mathrm{k}=$ Jumlah kolom, $\mathrm{b}=$ Jumlah baris

Pada uji kemaknaan hubungan, digunakan nilai alpha $5 \%(0,05)$. Dengan menggunakan SPSS, maka yang dicari adalah nilai $\mathrm{p}$ ( $p$ value $)$ sebagai nilai besarnya peluang hasil penelitian untuk menentukan keputusan uji statistik dengan cara membandingkan nilai $\mathrm{p}$ dengan nilai alpha. Ketentuan yang berlaku pada chi square koreksi $\mathrm{F}$. Yates adalah : (1) Bila p-value $\leq 0,05$ menunjukkan bahwa tidak ada hubungan yang bermakna antara variabel independen dengan 
variabel dependen; (2) Bila p-value > 0,05 menunjukkan bahwa ada hubungan yang bermakna antara variabel independen dengan variabel dependen.

\section{Model Penelitian}

Gambar 2. Model Penelitian

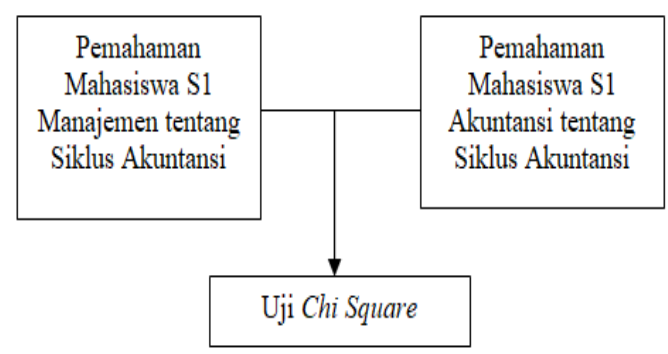

\section{HASIL DAN PEMBAHASAN} Gambaran Umum Responden

Tabel 2. Data Nilai Mahasiswa Program Studi S1 Akuntansi dan S1 Manajemen

\begin{tabular}{|c|c|c|c|c|c|c|c|c|c|c|c|}
\hline \multirow{2}{*}{ Prodi } & \multicolumn{4}{|c|}{ Nilai Perempuan } & \multicolumn{5}{|c|}{ Nilai Laki - laki } & \multirow{2}{*}{ Jumlah } \\
\cline { 2 - 10 } & A & B & C & D & E & A & B & C & D & E & \\
\hline $\begin{array}{c}\text { S1 } \\
\text { Manajemen }\end{array}$ & 6 & 17 & 2 & 1 & 3 & 2 & 15 & 2 & - & 2 & $\mathbf{5 0}$ \\
\hline $\begin{array}{c}\text { S1 } \\
\text { Akuntansi }\end{array}$ & 20 & 13 & 3 & 1 & 4 & 3 & 4 & 2 & - & - & $\mathbf{5 0}$ \\
\hline Jumlah & $\mathbf{2 6}$ & $\mathbf{3 0}$ & $\mathbf{5}$ & $\mathbf{2}$ & $\mathbf{7}$ & $\mathbf{5}$ & $\mathbf{1 9}$ & $\mathbf{4}$ & - & $\mathbf{2}$ & $\mathbf{1 0 0}$ \\
\hline
\end{tabular}

Tabel diatas menunjukkan bahwa mahasiswa S1 Akuntansi yang berjenis kelamin laki-laki yang mendapatkan nilai A sebanyak 3 orang, nilai B sebanyak 4 orang, nilai $C$ sebanyak 2 orang, nilai $\mathrm{D}$ dan $\mathrm{E}$ tidak ada. Adapun mahasiswa S1 Akuntansi yang berjenis kelamin perempuan yang mendapatkan nilai A sebanyak 20 orang, nilai B sebanyak 13 orang, nilai $C$ sebanyak 3 orang, nilai D sebanyak 1 orang dan nilai E sebanyak 4 orang.

Mahasiswa S1 Manajemen yang berjenis kelamin laki-laki yang mendapatkan nilai A sebanyak 2 orang, nilai B sebanyak 15 orang, nilai C sebanyak 2 orang, nilai D tidak ada dan nilai $\mathrm{E}$ sebanyak 2 orang. Sedangkan mahasiswa S1 Manajemen yang berjenis kelamin perempuan yang mendapatkan nilai A sebanyak 6 orang, nilai B sebanyak 17 orang, nilai C sebanyak 2 orang, nilai D sebanyak 1 orang dan nilai $\mathrm{E}$ sebanyak 3 orang.

\section{Statistik Deskriptif}

Tabel 3. Statistik Deskriptif

\begin{tabular}{|l|r|r|r|r|r|}
\hline & \multicolumn{1}{|c|}{$\mathrm{N}$} & \multicolumn{1}{c|}{ Minimum } & Maximum & \multicolumn{1}{c|}{ Mean } & Std. Deviation \\
\cline { 2 - 6 } & Statistic & \multicolumn{1}{c|}{ Statistic } & \multicolumn{1}{c|}{ Statistic } & Statistic & \multicolumn{1}{c|}{ Statistic } \\
\hline PRODI & 100 & 1 & 2 & 1.50 & .503 \\
JENIS_KELAMIN & 100 & 1 & 2 & 1.30 & .461 \\
NILAI & 100 & 10 & 92 & 71.26 & 17.889 \\
ValidN (listwise) & 100 & & & & \\
\hline
\end{tabular}

Berdasarkan tabel diatas, menunjukkan jumlah responden $(\mathrm{N})$ sebanyak 100. Dari 100 responden ini nilai mahasiswa terbesar (maksimum) adalah 10 dan nilai mahasiswa terkecil (minimum) adalah 92. Rata-rata nilai dari 100 responden atau Mean yakni sebesar 71,26 dengan Standard Deviasi sebesar 17,889.

\section{Hasil Analisa Data}

\section{Uji Koefisien Kontingensi Berdasarkan Program Studi dengan Nilai}

Tabel 4. Tabel Kontingensi Berdasarkan Program Studi dengan Nilai

\begin{tabular}{|c|c|c|c|c|c|c|}
\hline \multirow{2}{*}{$\begin{array}{c}\text { Program } \\
\text { Studi }\end{array}$} & \multicolumn{5}{|c|}{ Nilai } & \multirow{2}{*}{ Jumlah } \\
\cline { 2 - 7 } & A & B & C & D & E & \\
\hline Manajemen & 8 & 32 & 4 & 1 & 5 & 50 \\
\hline Akuntansi & 23 & 17 & 5 & 1 & 4 & 50 \\
\hline Jumlah & 31 & 49 & 9 & 2 & 9 & 100 \\
\hline
\end{tabular}

Berdasarkan tabel 4, menunjukkan bahwa nilai yang diperoleh oleh mahasiswa dari program studi Akuntansi dan Manajemen, antara lain nilai A (23 dan 8), nilai B (17 dan 32), nilai C (5 dan 4), nilai $\mathrm{D}$ (1 dan 1) dan E (4 dan 5).

Tabel 5. Tabel Frekuensi Kontingensi Berdasarkan Program Studi dengan Nilai

\begin{tabular}{|c|c|c|c|c|c|c|c|c|c|c|c|c|}
\hline \multirow{3}{*}{$\begin{array}{c}\text { Program } \\
\text { Studi }\end{array}$} & \multicolumn{7}{|c|}{ Nilai } & \multicolumn{2}{|c|}{ Jumlah } \\
\cline { 2 - 13 } & \multicolumn{2}{|c|}{ A } & \multicolumn{2}{|c|}{ B } & \multicolumn{2}{|c|}{ C } & \multicolumn{2}{c|}{ D } & \multicolumn{2}{|c|}{ E } & \multicolumn{2}{|c|}{} \\
\cline { 2 - 12 } & fo & fe & fo & fe & fo & fe & fo & fe & fo & fe & fo & fe \\
\hline Manajemen & 8 & 15,5 & 32 & 24,5 & 4 & 4,5 & 1 & 1 & 5 & 4,5 & 50 & 50 \\
\hline Akuntansi & 23 & 15,5 & 17 & 24,5 & 5 & 4,5 & 1 & 1 & 4 & 4,5 & 50 & 50 \\
\hline Jumlah & 31 & 31 & 49 & 49 & 9 & 9 & 2 & 2 & 9 & 9 & 100 & 100 \\
\hline
\end{tabular}

Hasil frekuensi dari tabel kontingensi (fo) dan hasil frekuensi dari tabel frekuensi kontingesi dimasukkan ke tabel 5

\section{Uji Bivariat Chi Square Berdasarkan Program Studi dengan Nilai}

Berdasarkan data pada tabel 5, langkah berikut uji Bivariat Chi Square seperti dibawah ini: 


$$
\begin{aligned}
& \mathrm{X}^{2} \text { hitung }=\left[\frac{\sum(\mathrm{fo}-\mathrm{fe})^{2}}{\mathrm{fe}}\right] \\
& \mathrm{X}^{2}=\frac{(8-15,5)^{2}}{15,5}+\frac{(32-24,5)^{2}}{24,5}+\frac{(4-4,5)^{2}+\frac{(1-1)^{2}}{4,5}+\frac{(5-4,5)^{2}}{1}+}{4,5}+ \\
& =\frac{(8-15,5)^{2}}{15,5}+\frac{(32-24,5)^{2}}{24,5}+\frac{(4-4,5)^{2}}{4,5}+(1-1)^{2}+(5-4,5)^{2} \\
& \mathrm{X}^{2}=3,629+2,296+0,056+0+0,056+3,629+2,296+0,056+0+0,056 \\
& \mathrm{X}^{2} \text { hitung }=12,074
\end{aligned}
$$

Langkah berikut adalah menentukan nilai $\mathrm{X}^{2}$ tabel sebagai berikut, Taraf signifikansi $(\alpha)=0,05$ kemudian Df $=($ Baris -1$)($ Kolom -1$)=(2-1)$ $(5-1)=4$ dan $\mathrm{X}^{2}$ tabel $=9,488$ kemudian menentukan kriteria pengujian, sebagai berikut : Jika $\mathrm{X}^{2}$ hitung $<\mathrm{X}^{2}$ tabel, maka Ho diterima dan Jika $\mathrm{X}^{2}$ hitung $>\mathrm{X}^{2}$ tabel, maka Ho ditolak. Selanjutnya membandingkan $X^{2}$ hitung dengan $X^{2}$ tabel : $X^{2}$ hitung $(12,074)>X^{2}$ tabel $(9,488)$.

Berdasarkan perhitungan di atas, maka dapat disimpulkan bahwa terdapat hubungan yang signifikan antara pemahaman mahasiswa S1 Akuntansi dan S1 manajemen tentang siklus akuntansi yang ditunjukkan berdasarkan hasil nilai yang diperoleh mahasiswa.

\begin{tabular}{|c|c|c|c|c|c|c|c|c|c|c|c|c|}
\hline \multirow{3}{*}{$\begin{array}{c}\text { Jenis } \\
\text { Kelamin }\end{array}$} & \multicolumn{10}{|c|}{ Nilai } & \multirow{2}{*}{\multicolumn{2}{|c|}{ Jumlah }} \\
\hline & \multicolumn{2}{|c|}{ A } & \multicolumn{2}{|c|}{ B } & \multicolumn{2}{|c|}{$\mathrm{C}$} & \multicolumn{2}{|c|}{ D } & & & \\
\hline & fo & fe & fo & fe & fo & fe & fo & fe & fo & fe & fo & fe \\
\hline Laki-laki & 5 & 9,3 & 19 & 14,7 & 4 & 2,7 & - & 0,6 & 2 & 2,7 & 30 & 30 \\
\hline Perempuan & 26 & 21,7 & 30 & 34,3 & 5 & 6,3 & 2 & 1,4 & 7 & 6,3 & 70 & 70 \\
\hline Jumlah & 31 & 31 & 49 & 49 & 9 & 9 & 2 & 2 & 9 & 9 & 100 & 100 \\
\hline
\end{tabular}

\section{Uji Koefisien Kontingensi Berdasarkan Jenis Kelamin dengan Nilai}

Tabel 6. Tabel Frekuensi Kontingensi Berdasarkan Jenis Kelamin dengan Nilai

Hasil frekuensi dari tabel kontingensi (fo) dan hasil frekuensi dari tabel frekuensi kontingesi dimasukkan ke tabel 6 .

\section{Uji Bivariat Chi Square Berdasarkan Program Studi dengan Nilai}

Berdasarkan data pada tabel 6, langkah berikut uji Bivariat Chi Square seperti dibawah ini :

$$
\begin{aligned}
& \mathrm{X}^{2} \text { hitung }=\frac{\sum(\mathrm{fo}-\mathrm{fe})^{2}}{\mathrm{fe}} \\
& \mathrm{X}^{2}=\frac{(5-9,3)^{2}}{9,3}+\frac{(19-14,7)^{2}}{14,7}+\frac{(4-2,7)^{2}}{2,7}+\frac{(0-0,6)^{2}}{0,6}+\frac{(2-2,7)^{2}}{2,7}+ \\
& =\frac{(26-21,7)^{2}}{21,7}+\frac{(30-34,3)^{2}}{34,3}+\frac{(5-6,3)^{2}}{6,3}+\frac{(2-1,4)^{2}}{1,3}+\frac{(7-6,3)^{2}}{6,3} \\
& \mathrm{X}^{2}=1,988+1,258+0,626+0,6+0,181+0,852+0,539+0,268+0,257+ \\
& \quad 0,778=7,347
\end{aligned}
$$

Langkah berikutnya adalah menentukan nilai $\mathrm{X}^{2}$ tabel sebagai berikut yaitu Taraf signifikansi $(\alpha)$ $=0,05$, kemudian Df $=($ Baris -1$)($ Kolom -1$)=$ $(2-1)(5-1)=4$ dan $X^{2}$ tabel $=9,488$. Kemudian menentukan kriteria pengujian, sebagai berikut : Jika $\mathrm{X}^{2}$ hitung $<\mathrm{X}^{2}$ tabel, maka Ho diterima dan Jika $X^{2}$ hitung $>X^{2}$ tabel, maka Ho ditolak. Selanjutnya membandingkan $\mathrm{X}^{2}$ hitung dengan $\mathrm{X}^{2}$ tabel : $X^{2}$ hitung $(7,347)<X^{2}$ tabel $(9,488)$.

\begin{tabular}{|c|c|c|c|c|c|}
\hline & & & Jenis $\mathrm{K}$ & $\operatorname{amin}$ & \\
\hline & & & Perempuan & Laki-laki & Total \\
\hline & & Count & 1972 & 1421 & 3393 \\
\hline & Manaiemen & Expected Count & 2385.5 & 1007.5 & 3393.0 \\
\hline & Nididaferient & Residual & -413.5 & 413.5 & \\
\hline Program Studi & & Adjusted Residual & -21.5 & 21.5 & \\
\hline Fiograll_sudu & & Count & 3038 & 695 & 3733 \\
\hline & & Expected Count & 2624.5 & 1108.5 & 3733.0 \\
\hline & Akuntansi & Residual & 413.5 & -413.5 & \\
\hline & & Adjusted Residual & 21.5 & -21.5 & \\
\hline Total & & & 5010 & 2116 & 7126 \\
\hline
\end{tabular}

Berdasarkan perhitungan di atas, maka dapat disimpulkan bahwa tidak terdapat hubungan yang signifikan antara pemahaman mahasiswa S1 Akuntansi dan S1 manajemen berdasarkan jenis kelamin tentang siklus akuntansi yang ditunjukkan berdasarkan hasil nilai yang diperoleh mahasiswa.

\section{Uji Chi Square Menggunakan SPSS}

Tabel 7. Program_Studi*Jenis_Kelamin Crosstabulation

Hasil Output pada tabel 7, Program_Studi*Jenis_Kelamin_Crosstabulation dapat di interpretasikan bahwa nilai Adjusted Residual yang cukup besar (dengan nilai absolut 21,5), hal ini menunjukan deviasi atau perbedaan yang besar pada setiap sel dari nilai yang diharapkan. Nilai Residual merupakan selisih antar nilai Observed dengan Expected Frequency menjauh dari nol. Jika hipotesis awal benar, maka kita mengharapkan nilai residualnya akan menjadi nol atau mendekati nol.

Tabel 8. Chi-SquareTest

\begin{tabular}{|l|r|c|r|r|r|}
\hline & Value & df & $\begin{array}{c}\text { Asymp. } \\
\text { Sig. } \\
\text { (2-sided) }\end{array}$ & $\begin{array}{c}\text { Exact. Sig. } \\
\text { (2-sided) }\end{array}$ & $\begin{array}{c}\text { Exact. Sig. } \\
\text { (1-sided) }\end{array}$ \\
\hline $\begin{array}{l}\text { Pearson Chi-Square } \\
\text { Continuity }\end{array}$ & $460.735^{\mathrm{s}}$ & 1 & .000 & & \\
$\begin{array}{l}\text { Correction } \\
\text { Likelihood Ratio }\end{array}$ & 459.621 & 1 & .000 & & \\
$\begin{array}{l}\text { Fisher's Exact Test } \\
\text { Linear-by-Linear }\end{array}$ & 466.556 & 1 & .000 & & .000 \\
$\begin{array}{l}\text { Association } \\
\text { N of Valid Cases }\end{array}$ & 460.670 & 1 & .000 & & .000 \\
\hline
\end{tabular}

Hasil Output untuk tabel 5.10 Chi-Square Test dapat diinterpretasikan bahwa nilai dari Pearson Chi-Square adalah $460.735^{\mathrm{a}}$ dan $p$-value $<0,0001$ sehingga dapat diambil kesimpulan bahwa terdapat hubungan yang signifikan antara pemahaman mahasiswa program studi S1 Manajemen dan S1 Akuntansi tentang Siklus Akuntansi dengan hasil nilai pada taraf signifikansi $5 \%$. Hasil ini juga sejalan dengan uji Likelihood Ratio dimana nilainya adalah 466.556 dan p-value $<0,001$ 
karena nilai $p$-value $<0,05$ tolak hipotesis awal juga.

\section{Pembahasan}

Pemahaman Mahasiswa S1 Manajemen tentang Siklus Akuntansi

Pemahaman dalam pembelajaran menurut Sudjana (2008) adalah tingkat kemampuan yang mengharapkan seseorang mampu memahami arti atau konsep, situasi serta fakta yang diketahuinya. Hal ini tidak hanya hafal secara verbalitas, tetapi memahami konsep dari masalah atau fakta yang ditanyakan, maka operasionalnya dapat membedakan, mengubah, mempersiapkan, menyajikan, mengatur, menginterpretasikan, memberi contoh, memperkirakan, menentukan dan mengambil keputusan.

Berdasarkan hasil output nilai Expected Count sebesar 2385,5 pada mahasiswa S1 Manajemen yang berjenis kelamin perempuan sedangkan nilai Expected Count pada mahasiswa S1 Manajemen yang berjenis kelamin laki-laki sebesar 1007,5. Hal ini menunjukkan bahwa pemahaman mahasiswa S1 Manajemen yang berjenis kelamin perempuan lebih tinggi dibandingkan dengan pemahaman mahasiswa S1 Manajemen yang berjenis kelamin laki-laki.

Berdasarkan pendapat ahli dan berdasarkan output hasil uji, penelitian ini didukung penelitian yang dilakukan oleh Novius (2010), bahwa tidak terdapat perbedaan secara signifikan terhadap pemahaman tentang akuntansi antara mahasiswa yang berasal dari berbagai jurusan ataupun jenis kelamin. Artinya pemahaman mahasiswa terhadap siklus akuntansi tidaklah berbeda ataupun identik antara satu sama lainnya tidaklah menjadi faktor perbedaan bagi mahasiswa untuk memahami siklus akuntansi.

\section{Pemahaman Mahasiswa S1 Akuntansi tentang Siklus Akuntansi}

Fajri dan Senja (2008), menjelaskan bahwa pemahaman berasal dari kata paham yang mempunyai arti mengerti benar, sedangkan pemahaman merupakan proses perbuatan cara memahami. Dengan kata lain, memahami adalah mengetahui tentang sesuatu dan dapat melihatnya dalam berbagai segi. Seseorang dikatakan memahami suatu hal apabila ia dapat memberikan penjelasan dan meniru hal tersebut dengan menggunakan kata-katanya sendiri.

Berdasarkan hasil output nilai Expected Count sebesar 2624.5 pada mahasiswa S1 Akuntansi yang berjenis kelamin perempuan sedangkan nilai Expected Count pada mahasiswa S1 Akuntansi yang berjenis kelamin laki-laki sebesar 1108,5. Hal ini menunjukkan bahwa pemahaman mahasiswa S1 Akuntansi yang berjenis kelamin perempuan lebih tinggi dibandingkan dengan pemahaman mahasiswa S1 Akuntansi yang berjenis kelamin laki-laki.

Berdasarkan pendapat ahli dan berdasarkan output hasil uji, penelitian ini didukung penelitian yang dilakukan oleh Biduri (2016), bahwa tidak ada perbedaan pemahaman konsep dasar akuntansi yang signifikan antara mahasiswa dari berbagai latar belakang. Artinya pemahaman mahasiswa terhadap siklus akuntansi tidaklah berbeda ataupun identik antara satu sama lainnya tidaklah menjadi faktor perbedaan bagi mahasiswa untuk memahami siklus akuntansi.

\section{Perbedaan Pemahaman Mahasiswa S1 Manajemen dan S1 Akuntansi tentang Siklus Akuntansi}

Menurut Gardner (2011), pemahaman lebih tinggi satu tingkat dari hafalan. Pemahaman memerlukan kemampuan menangkap makna atau arti dari suatu konsep, maka diperlukan adanya hubungan atau pertautan antara konsep dan makna atau arti dari suatu konsep. Definisi lain bahwa pemahaman adalah salah satu aspek dalam belajar yang digunakan sebagai dasar mengembangkan model pembelajaran dengan memperhatikan indikator pemahaman.

Berdasarkan hasil output pada tabel 5.9, Nilai Expected Count sebesar 2385,5 pada mahasiswa S1 Manajemen yang berjenis kelamin perempuan sedangkan nilai Expected Count pada mahasiswa S1 Manajemen yang berjenis kelamin laki-laki sebesar 1007,5. Sedangkan Nilai Expected Count sebesar 2624.5 pada mahasiswa S1 Akuntansi yang berjenis kelamin perempuan sedangkan nilai Expected Count pada mahasiswa S1 Akuntansi yang berjenis kelamin laki-laki sebesar 1108,5. Hal ini menunjukkan bahwa pemahaman mahasiswa S1 Akuntansi baik yang berjenis kelamin perempuan maupun laki-laki lebih tinggi dibandingkan dengan pemahaman mahasiswa S1 Manajemen yang berjenis kelamin perempuan dan laki-laki.

Berdasarkan pendapat ahli dan berdasarkan output hasil uji, penelitian ini didukung penelitian yang dilakukan oleh Novius (2010) dan Biduri (2016), bahwa tidak ada perbedaan pemahaman konsep dasar akuntansi yang signifikan antara mahasiswa dari berbagai latar belakang. Artinya pemahaman mahasiswa terhadap siklus akuntansi tidaklah berbeda ataupun identik antara satu sama 
lainnya tidaklah menjadi faktor perbedaan bagi mahasiswa untuk memahami siklus akuntansi.

Tabel 9. Rekapitulasi Nilai Akuntansi Berdasarkan Program Studi Dan Jenis Kelamin

\begin{tabular}{|c|c|c|c|c|c|c|c|}
\hline \multirow{2}{*}{$\begin{array}{c}\text { Program } \\
\text { Studi }\end{array}$} & Jenis & \multicolumn{5}{|c|}{ Nilai } & \multirow{2}{*}{ Kumlah } \\
\cline { 3 - 7 } Kelamin & A & B & C & D & E & \\
\hline S1 & Laki-laki & 2 & 15 & 2 & - & 2 & 21 \\
\cline { 2 - 7 } Manajemen & Perempuan & 6 & 17 & 2 & 1 & 3 & 29 \\
\hline \multirow{2}{*}{$\begin{array}{c}\text { S1 } \\
\text { Akuntansi }\end{array}$} & Laki-1aki & 3 & 4 & 2 & - & - & 9 \\
\cline { 2 - 7 } & Perempuan & 20 & 13 & 3 & 1 & 4 & 41 \\
\hline \multicolumn{2}{|c|}{ Jumlah } & 31 & 49 & 9 & 2 & 9 & 100 \\
\hline
\end{tabular}

Berdasarkan table 9, diketahui bahwa nilai A untuk mahasiswa program studi S1 Akuntansi sebanyak 23 orang sedangkan untuk mahasiswa program studi S1 Manajemen sebanyak 8 orang. Nilai A untuk mahasiswa yang berjenis kelamin laki-laki sebanyak 5 orang sedangkan untuk mahasiswa yang berjenis kelamin perempuan sebanyak 26 orang. Disimpulkan bahwa mahasiswa untuk program studi S1 Akuntansi lebih paham tentang siklus akuntansi dibandingkan dengan mahasiswa untuk program studi S1 Manajemen. Adapun mahasiswa perempuan lebih paham tentang siklus akuntansi dibandingkan dengan mahasiswa laki-laki.

Perbedaan pemahaman tersebut disebabkan karena materi pembelajaran akuntansi untuk mahasiswa program studi S1 Akuntansi lebih banyak praktikum atau prakteknya, mahasiswa perempuan lebih rajin dalam mengerjakan tugas dan latihan-latihan yang diberikan sedangkan mahasiswa laki-laki hanya berprinsip asal masuk kuliah.

\section{KESIMPULAN DAN SARAN}

\section{Kesimpulan}

Berdasarkan uji koefisien kontingensi, dapat disimpulkan bahwa terdapat hubungan yang signifikan antara pemahaman mahasiswa S1 Akuntansi dan S1 manajemen tentang siklus akuntansi yang ditunjukkan berdasarkan hasil nilai yang diperoleh mahasiswa. Akan tetapi tidak terdapat hubungan yang signifikan antara pemahaman mahasiswa S1 Akuntansi dan S1 manajemen berdasarkan jenis kelamin tentang siklus akuntansi yang ditunjukkan berdasarkan hasil nilai yang diperoleh mahasiswa.

Berdasarkan uji Pearson Chi-Square dan uji Likelihood Ratio, dapat disimpulkan bahwa terdapat hubungan yang signifikan antara pemahaman mahasiswa program studi S1 Manajemen dan S1 Akuntansi tentang Siklus Akuntansi yang ditunjukkan pada hasil nilai mahasiswa.
Pemahaman mahasiswa tentang siklus akuntansi baik pada program studi S1 manajemen maupun S1 Akuntansi, disimpulkan bahwa pemahaman mahasiswa perempuan lebih tinggi dibandingkan dengan pemahaman mahasiswa lakilaki. Demikian pula, pemahaman mahasiswa S1 Akuntansi tentang siklus akuntansi lebih tinggi dibandingkan dengan pemahasiswa S1 Manajemen. Hal ini disebabkan karena pemberian materi akuntansi untuk masing-masing program studi berbeda, prosentase praktek lebih tinggi dibandingkan teori untuk program studi S1Akuntansi, sedangkan untuk S1 manajemen prosentase teori lebih tinggi dibandingkan praktek. Mahasiswa perempuan lebih rajin dalam mengerjakan tugas dan latihan-latihan yang diberikan sedangkan mahasiswa laki-laki hanya berprinsip asal masuk kuliah.

\section{Implikasi \\ Implikasi Teoritis}

Implikasi dari penelitian ini adalah dengan adanya tambahan wawasan dan pandangan bagi mahasiswa S1 Manajemen dan S1 Akuntansi tentang siklus akuntansi baik siklus tahap awal (Jurnal, Buku Besar, Neraca Saldo) maupun siklus tahap penyelesaian (Jurnal Penyesuaian, Neraca lajur, Laporan Keuangan, Jurnal Penutup) untuk lebih meningkatkan belajar agar pemahamannya tentang siklus akuntansi dapat ditingkatkan.

\section{Implikasi Praktis}

Bagi penelitian selanjutnya, hasil penelitian ini dapat menjadi referensi pada penelitian berikutnya yaitu dapat digunakan sebagai dasar untuk melakukan modifikasi dengan memasukkan variabel lain yang berhubungan dengan pemahaman tentang siklus akuntansi.

\section{Keterbatasan Penelitian}

Pada penelitian ini, hanya mengambil 100 responden yang terdiri dari 50 responden $\mathrm{S} 1$ manajemen dan 50 responden S1 Akuntansi, sehingga dalam mengevaluasi mahasiswa belum dapat maksimal.

\section{Saran}

Untuk penelitian mendatang, diharapkan dapat menjelaskan menambah jumlah responden, agar lebih dapat diketahui tingkat pemahaman mahasiswa tentang mata kulah akuntansi. 


\section{DAFTAR PUSTAKA}

Arikunto, Suharsimi. (2009). Dasar-dasar Evaluasi Pendidikan. Jakarta:Bumi Aksara

Arikunto, S. 2010. Prosedur Penelitian Suatu Pendekatan Praktik. Jakarta: Rineka Cipta

Anas Sudijono. 2009. Pengantar Statistik Pendidikan. Jakarta: Rajawali pers

Anas Sudijono. 2013. Pengantar Evaluasi pendidikan. PT. Raja Grafindo Persada. Jakarta

Agung Kresnamurti R.P dan Ariani Putri. 2012." Pengaruh kualitas produk dan citra merek terhadap loyalitas konsumen pada produk oli federal di wilayah Jakarta Timur". Econo Sains. Vol.10. No.1.

Agustina dan Debi Melda Yanti. 2015. Analisis Faktor-faktor Yang Mempengaruhi Akuntansi Tingkat Pemahaman Akuntansi Mahasiswa Jurusan Akuntansi STIE Microskill Medan. Jurnal Wira Ekonomi Mikroskil Volume 5, Nomor 01, April 2015

Anton Mulyono Aziz dan Maya Irjayanti, 2014, Manajemen. Bandung, Mardika Group

Biduri, Sarwenda. 2016. Pengaruh Pemahaman Mahasiswa Akuntansi Terhadap Konsep Dasar Akuntansi Dengan Latar Belakang Sekolah Menengah Yang Berbeda Pada Universitas Muhammadiyah Sidoarjo Jawa Timur. Prosiding Seminar Nasional Ekonomi dan Bisnis \& Call For Paper FEB UMSIDA. Hal 512 - 527

Budi Hartono dan Nuraninun Bangun. 2011. Analisis Pemahaman Mahasiswa Akuntansi Terhadap Konsep Aset, Kewajiban Dan Ekuitas. Jurnal Bisnis Dan Akuntansi. Vol 13 No 3, Hlm 183 -194

Daryanto (2008). Evaluasi Pendidikan. Jakarta. Rineka Citra

Dina Fitria. 2014. Buku Pintar Akuntansi Untuk Orang Awam \& Pemula, Jakarta Timur: Laskar Aksara.

Efriyenti, Dian. 2017. Analisis Tingkat Pemahaman Mahasiswa Akuntansi
Terhadap Konsep dasar Akuntansi ( Studi Empiris Pada mahasiswa Akuntansi Di Unversitas Internasional Batam). Pekbis Jurnal, Vol.9, No.3, November 2017:241252

EM Zul Fajri dan Ratu Aprilia Senja, 2008. Kamus Lengkap Bahasa Indonesia, Edisi Revisi, Cet. 3, Semarang: Difa Publishers

Gardner, H. (2011). Frames of Mind. New York: Basic Book.

Ghozali, Imam. 2012. Aplikasi Analisis Multivariate dengan Program IBM SPSS 20. Semarang: Badan Penerbit Universitas Diponegoro.

Ghozali, Imam. 2016. Aplikasi Analisis Multivariete Dengan Program IBM SPSS 23 (Edisi 8). Cetakan ke VIII. Semarang : Badan Penerbit Universitas Diponegoro

Hans Kartikahadi., dkk. 2016. Akuntansi Keuangan Berdasarkan SAK Berbasis IFRS Buku 1. Jakarta : Salemba Empat.

Hery, 2014, "Pengendalian Akuntansi dan Manajemen”, Kencana, Jakarta

Krismiaji, 2015. Sistem Informasi Akuntansi. Edisi Keempat.Yogyakarta : UPP STIM YKPN.

Kieso, Donald E. Jerry J.Weygandt, Paul D. Kimmel. 2014. Accounting Principles Pengantar Akuntansi Edisi 7 Jilid 1. Jakarta: Salemba Empat.

McLeod R \& Schell GP. 2009. Sistem Informasi Manajemen, Edisi 11, Terjemahan. Jakarta: Salemba Empat.

Nana Sudjana, 2008. Penilaian Hasil Proses Belajar Mengajar. Bandung: Remaja Rosdakarya

Novius, Andri. 2010. Analisis Pemahaman Mahasiswa Akuntansi Dalam Menghadapi Mata Kuliah Dasar-dasar Akuntansi (Studi Pada Mahasiswa S1 Akuntansi Universitas Islam Negeri Sultan syarif Kasim Riau). Fokus Ekonomi Vol. 5 No. 2 Desember $2010: 44-60$ 
Dinamika Sosial Budaya, Vol 21, No. 1, Juni 2019, pp 47-56

p-ISSN: 1410-9859\& e-ISSN: 2580-8524

http://journals.usm.ac.id/index.php/jdsb

Notoatmodjo, S. 2010. Metodologi Penelitian Kesehatan. Jakarta : Rineka Cipta

Pura, Rahman, Pengantar Akuntansi 1 Pendekatan Siklus Akuntansi, Jakarta: Penerbit Erlangga, 2013. Qardawi

Rusmita, Sari. 2012. Analisis Tingkat Pemahaman Mahasiswa Akuntansi terhadap Konsep Dasar Akuntansi Berdasarkan Asal Sekolah. Jurnal Ekonomi Bisnis dan Kewirausahaan 2012, Vol. 3, No. 1, 85-94

Sri Maryati. 2017. Faktor-faktor Yang Mempengaruhi Tingkat Pemahaman akuntansi (Studi Empiris pada Mahasiswa AkuntansiIBI Darmajaya Lampung). GEMA -VolumeIX, Nomor 1,Januari 2017. ISSN 2086-9592

Sugiyono, 2009, Metode Penelitian Kuantitatif, Kualitatif dan $R \& D$, Bandung : Alfabeta.

Sugiyono. 2014. Metode Penelitian Pendidikan Pendekatan Kuantitatif, Kualitatif Dan $R \& D$. Bandung: Alfabeta.

Sugiyono. (2017). Metode Penelitian Kuantitatif, Kualitatif, dan $R \& D$. Bandung : Alfabeta, CV.

Titisari, Kartika Hendra; Anita Wijayanti dan Yuli Chomsatun. Model Pembelajaran Akuntansi Untuk Meningkatkan Kompetensi Mahasiswa. Jurnal Buletin Studi Ekonomi, Vol. 18, No. 2, Agustus 2013. Hal : 126 - 135

Warsidi CA. 2017. Siklus akuntansi: tahap-tahap proses akuntansi. Warsidi.com https://goo.gl/Jd3aEv 